\title{
Tinjauan Pelepasan Informasi Rekam Medis Kepada Pihak Ketiga Di RSU Imelda Pekerja Indonesia Medan
}

\author{
Erlindai $^{1}$, Hesty Afriani Sidabutar ${ }^{2}$ \\ ${ }^{1,2}$ Program Studi D-3 Perekam dan Informasi Kesehatan, Universitas Imelda Medan
}

\begin{tabular}{l}
\hline Article Info \\
\hline Article history: \\
Received Jan 09, 2021 \\
Revised Jul 28, 2021 \\
Accepted August 23, 2021 \\
\end{tabular}

Keywords:

Review

Medical Record Files

Medical Record Information

Management (MIRM) 13.4

\begin{abstract}
Imelda General Hospital of Indonesian Workers does not yet have a fixed SOP (Standard Operating Procedure) specifically regarding the release of medical record information to third parties, but there is already a regulation in the form of a system for releasing medical record information. This study aims to determine the number of requests for medical record information. This study aims to determine the number of requests for medical record information. This type of research is descriptive, namely the research method carried out with the aim of making an objective situation. The population is 4 people and all medical record files are released to third parties with a research methodology using qualitative methods. How to collect data by interview and observation. The results showed that the IPI RSU service, directed medical record documents released to third parties for the purposes of raharja service claims, namely 56 files $(0.92 \%)$, insurance needs 69 files $(1.13 \%)$, BPJS needs 5.790 files $(95.06 \%)$, research needs are 54 files $(0.89 \%)$, research is 58 files $(0.95)$, education is 58 files $(0.95 \%)$, court is 36 files $(0.59 \%)$ and the need for visum et revertrum is 28 files $(0.46 \%)$. Based on the results of the study, it is known that knowing the data on the number of requests for medical record information in January-June 2020 amounted to 6,091 medical record files, until now RSU IPI has not had a special SOP for the release of information. It is recommended for hospitals to make SOPs regarding information release procedures so that officers are able to provide optimal services regarding the release of information to parties who require the release of medical record information.
\end{abstract}

This is an open access article under the CC BY-SAlicense.

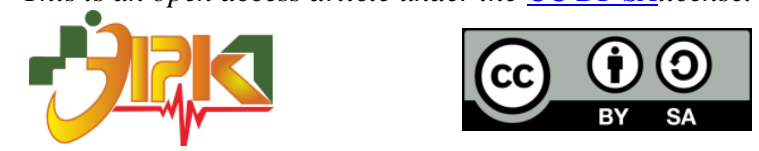

\section{Corresponding Author:}

Erlindai,

Program Studi D-3 Perekam dan Informasi Kesehatan,

Universitas Imelda Medan,

Jl. Bilal No. 52 Kelurahan Pulo Brayan Darat I Kecamatan Medan Timur, Medan - Sumatera Utara.

Email: erigaaritonang291087@gmail.com

\section{PENDAHULUAN}

Rumah sakit adalah institusi pelayanan kesehatan yang menyelenggarakan pelayanan kesehatan perorangan secara paripurna yang mnyediakan pelayanan rawat inap, rawat jalan dan gawat darurat. Upaya kesehatan diselenggarakan dengan pendekatan peningkatan kesehatan (promotif), pencegahan penyakit (preventif), penyembuhan penyakit (kuratif), 
dan pemulihan (rehabilitatif) yang dilaksanakan secara menyeluruh, terpadu dan berkesinambungan [1].

Berdasarkan [2] dikatakan bahwa sarana pelayanan kesehatan wajib menyediakan fasilitas yang diperlukan dalam rangka penyelenggaraan rekam medis. Rekam medis adalah dokumentasi rekam jejak pasien dimana berisikan catatan tentang biodata pasien, tindakan pemeriksaan, hal pengobatan serta tindakan juga pelayanan lain kepada pasien pada sarana pelayanan kesehatan [3].

Rekam medis memiliki peranan penting sebagai bukti dasar fisik yang memonitor segala jejak dari data pasien didalam mendapatkan pelayanan dirumah sakit yang merekam segala tindakan pengobatan klien dirumah sakit selama perawatan dan sebagai bukti autentik jika diminta oleh hukum, sebagai bentuk bukti yang digunakan didalam penelitian dan juga sebagai bahan pembelajaran bagi dunia pendidikan untuk mendapatkan data, berguna untuk pengkleman pembiayaan pelayanan selama pengobatan dan juga untuk menaikkan data statistik kesehatan [4].

Menurut [5] tentang rekam medis, menyatakan bahwa informasi tentang identitas, diagnosis, riwayat penyakit, riwayat pemeriksaan dan riwayat pengobatan dapat dibuka dalam hal untuk kepentingan kesehatan pasien, memenuhi permintaan aparatur penegak hukum dalam rangka penegakan hukum atas perintah pengadilan, permintaan dan/atau persetujuan pasien sendiri, permintaan institusi/lembaga berdasarkan ketentuan perundangundangan dan untuk kepentingan penelitian, pendidikan, dan audit medis, sepanjang tidak menyebutkan identitas pasien.

Dipastikan secara keseluruhan dari isi dokumen dijamin keamanan, privasi, kerahasiaan juga keselamatan adalah informasi dalam rekam medis. Rumah sakit selaku pemilik informasi data rekam medis harus memiliki prosedur pelepasan atau pemberian informasi rekam medis yang sejalan dengan [6]. "Penjelasan tentang praktik kedokteran, dokumen rekam medis merupakan milik dokter, dokter gigi, atau sarana pelayanan kesehatan, sedangkan isi rekam medis merupakan milik pasien".

Hasil penelitian [7] tentang "Analisis Sistem Pelepasan Informasi Rekam Medis Dalam Menjamin Aspek Hukum Kerahasiaan Rekam Medis Di Rumah Sakit Imelda Pekerja Indonesia Medan” berdasarkan penelitian ini bahwa sistem pelepasan informasi RSU Imelda pekerja Indonesia Medan sudah optimal dan sudah melaksanakan SPO sesuai ketentuan yang sudah diatur dirumah sakit tersebut yang menjadi acuhan dalam hal melakukan tindakan.

Hasil penelitian [8] "Tinjauan Pelaksanaan Pelepasan Informasi Medis Kepada Pihak Ketiga Untuk Kaim Asuransi Di Rumah Sakit Muhammadiyah Taman Puring Jakarta" bahwa berdasarkan penelitian ini bahwa pada pelaksanaan pelepasan informasi medis dan SPO mengenai kebijakan persyaratan pelapasan informasi medis yaitu surat kuasa bermaterai 6000, foto copy identitas pasien dan identitas pihak ketiga, ditemukan 14 (34\%) dari 41 permintaan dokumen rekam medis dari pihak ketiga tidak lengkap. Kemudian hasil penelitian [9] "Tinjauan Prosedur Pelepasan Informasi Rekam Medis Untuk Keperluan Klaim BPJS Di RSU Darmayu Ponorogo" belum adanya SOP yang khusus untuk bagian asuransi BPJS dan untuk pihak yang terlibat dalam pelepasan informasi rekam medis.

Berdasarkan survey pendahuluan di RSU Imelda Pekerja Indonesia, dari proses pelaksanaan pelepasan suatu informasi rekam medis pasien pada pihak ketiga sudah ada regulasi sistem pelepasan informasi akan tetapi masih ada tenaga rekam medis yang belum mengikuti regulasi yang ada. Berdasarkan data yang ditemukan tersebut maka perlu diadakan penelitian tentang "Tinjauan Pelepasan Informasi Rekam Medis Kepada Pihak Ketiga di RSU Imelda Pekerja Indonesia Medan”. 


\section{METODE PENELITIAN}

A. Jenis Penelitian

Jenis penelitan ini dilakukan dengan menggunakan metode penelitian kualitatif. Penelitian ini dilakukan dalam keadaan situasi alami, sehingga tidak ada pembatasan dalam memaknai atau memahami penelitian yang dikaji di RSU IPI Medan Tahun 2020.

B. Populasi

Populasi adalah semua hasil atau nilai yang memungkinkan, baik dari hasil perhitungan atau mengukur kualitatif tentang karakteristik tertentu sebagai dasar dari semua elemen himpunan dari data yang ingin diteliti sifat-sifatnya [10]. Populasi dalam penelitian ini berjumlah 4 orang petugas rekam medis dibagian asuransi dan seluruh berkas rekam medis yang berjumlan 6.091 berkas yang dilepaskan kepada pihak ketiga.

C. Sampel

Sampel merupakan sebagian dari seluruh elemen yang menjadi objek penelitian [10]. Sampel dalam penelitian ini adalah sampling jenuh artinya jumlah populasi sama dengan jumlah sampel yaitu berjumlah 4 orang. Sampel dalam penelitian adalah dokumen rekam medis yang dilepaskan kepada pihak ketiga dalam enam bulan terakhir yaitu pada Januari-Juni 2020 sejumlah 6.091 berkas.

\section{HASIL DAN PEMBAHASAN}

\subsection{Hasil}

Berdasarkan penelitian dan pengumpulan data yang dilakukan oleh peneliti mengenai "Tinjauan Pelepasan Informasi Kepada pihak ketiga di RSU Imelda Pekerja Indonesia Medan". Adapun hasil yang diperoleh peneliti mengenai prosedur dan pelepasan informasi rekam medis adalah sebagai berikut.

Tabel 1. Distribusi Jumlah Berdasarkan Klaim Jasa Raharja, Asuransi, BPJS, Penelitian, Pendidikan, Pengadilan dan Visum Et Revertrum

\begin{tabular}{clcc}
\hline No & Keperluan Penggunaan Informasi & Jumlah Berkas & Persentase \% \\
\hline 1 & Klaim jasa raharja/BPJS & 56 & 0,92 \\
\hline 2 & Asuransi & 69 & 1,13 \\
\hline 3 & BPJS & 5.790 & 95,06 \\
\hline 4 & Penelitian & 54 & 0,89 \\
\hline 5 & Pendidikan & 58 & 0,95 \\
\hline 6 & Pengadilan & 36 & 0,59 \\
\hline 7 & Visum et revertrum & 28 & 0,46 \\
\hline & Jumlah & $\mathbf{6 . 0 9 1}$ & $\mathbf{1 0 0}$ \\
\hline
\end{tabular}

Berdasarkan tabel di atas menujukan dokumen rekam medis yang dilepaskan kepada pihak ketiga untuk keperluan klaim jasa raharja yaitu 56 berkas $(0,92 \%)$, keperluan asuransi yaitu 69 berkas (1,13\%), keperluan BPJS yaitu 5.790 berkas $(95,06 \%)$, keperluan penelitian yaitu 54 berkas $(0,89 \%)$, pendidikan yaitu 58 berkas $(0,95)$, pengadilan yaitu 36 berkas $(0,59 \%)$ dan keperluan visum et revertrum yaitu 28 berkas $(0,46 \%)$.

\subsection{Pembahasan}

\section{Berdasarkan Klaim Jasa Raharja, Asuransi, BPJS, Penelitian, Pendidikan,} Pengadilan dan Visum Et Revertrum

Berdasarkan hasil didapatkan bahwa dokumen rekam medis yang dilepaskan kepada pihak ketiga untuk keperluan klaim jasa raharja yaitu 56 berkas $(0,92 \%)$, keperluan asuransi yaitu 69 berkas $(1,13 \%)$, keperluan BPJS yaitu 5.790 berkas $(95,06 \%)$, keperluan 
penelitian yaitu 54 berkas $(0,89 \%)$, pendidikan yaitu 58 berkas $(0,95)$, pengadilan yaitu 36 berkas $(0,59 \%)$ dan keperluan visum yaitu 28 berkas $(0,46 \%)$.

Menurut [5] tentang pelepasan informasi bisa diberikan kepada pihak ketiga untuk kepentingan kesehatan pasien, memenuhi permintaan aparatur penegak hukum atas perintah pengadilan, permintaan persetujuan pasien sendiri, permintaan institusi lembaga, kepentingan penelitian, pendidikan dan audit medis, sepanjang tidak menyebutkan identitas pasien.

Berdasarkan hasil wawancara kepada petugas rekam medis yang berjumlah 4 orang tentang pelepasan informasi kepada pihak ketiga yang meminta pelepasan informasi, informan mengatakan bahwa:

"biasanya pelepasan informasi itu diminta sama keluarga pasien, asuransi, data untuk penelitian". (Informan 1)

"yang saya lakukan kalau ada pihak asuransi yang meminta berkas untuk pengkleman asuransi dan keperluan jasa raharja”. (Informan 2)

"sama keluarga pasien, asuransi dan pernah juga diminta sama pihak pengadilan dan klaim jasa raharja,penelitian dan PKL mahasiswa”. (Informan 3)

"saya pernah memberikan informasi kepada penegak hukum dengan memberikan surat permintaan Visum et revertum”. (Informan 4)

Berdasarkan hasil wawancara tentang proses pelepasan informasi, informan menjelaskan bahwa:

"misalkan kalau ada pasien/keluarga yang meminta berkas rekam medis, data medis pasien dapat diberikan kepada keluarga/ ahli waris pasien dengan membawa fotocopi KTP dan kartu keluarga", jika ada pihak asuransi yang meminta berkas rekam medis, permintaan akan diberikan berdasarkan permintaan tertulis dar pihak pemohon dan dilampirkan surat kuasa dari pasien/keluarga yang disetujui oleh Direktur RSU Imelda Pekerja Indonesia, untuk keperluan penelitian sebaiknya peneliti membawa surat izin penelitian dari kampus dan dan harus dibuat adanya persetujuan pasien atas pelepasan informasi data rekam medisnya". (Informan 1)

"adapun yang saya lakukan jika ada pihak asuransi yang meminta berkas rekam medis untuk keperluan, harus membuat permintaan tertulis dari pihak pemohon dan dilampirkan surat kuasa dari pasien/ keluarga”. (Informan 2)

"yang saya lakukan jika ada pihak keluarga pasien yang meminta pelepasan berkas rekam medis, maka saya akan memberikan kepada keluarga dengan membawa surat pernyataan tertulis", "saya juga sudah pernah diminta pihak pengadilan tentang data dan informasi rekam medis dapat diberikan jika pihak hukum memberikan surat permintaan visum et revertum". Juga pernah diminta oleh mahasiswa praktek untuk keperluan penelitian da laporan PKL dengan membawa surat izin penelitian. (Informan 3)

"jika ada yang meminta pelepasan informasi Visum et revertum saya akan meminta bukti tertulis dari pengadilan yang ditujukan kepada Direktur, setelah itu berkas dapat diberikan”. (Informan 4)

Proses pelepasan informasi harus dilakukan berdasarkan SOP rumah sakit yang digunakan dirumah sakit, namun Rumah Sakit IPI tidak memiliki SOP melainkan dalam bentuk regulasi. Hal ini dibuktikan dari hasil wawancara informan bahwa pelaksanaan pelepasan informasi yang yang mereka lakukan berbeda-beda prosesnya.

SOP merupakan instruksi yang berisikan langkah-langkah suatu proses kerja rutin tertentu yang disusun berdasarkan konsensus bersama yang dibuat oleh fasilitas layanan kesehatan berdasarkan standar profesi (Permenkes RI No. 512 Tahun 2007). [2] pada pasal 10 tentang pelepasan informasi untuk kepentingan aparatur penegak hukum atas perintah pengadilan, permintaan atau persetujuan pasien sendiri, permintaan institusi/lembaga, untuk kepentingan penelitian, pendidikan, dan audit medis. 


\section{KESIMPULAN} berikut:

Dari hasil penelitian yang dilakukan oleh peneliti didapatkan kesimpulan sebagai

1. Pelepasan informasi medis Di RSU Imelda Pekerja Indonesia Medan pada bulan Januari-Juni 2020 untuk keperluan klaim jasa raharja yaitu 56 berkas $(0,92 \%)$, keperluan asuransi yaitu 69 berkas (1,13\%), keperluan BPJS yaitu 5.790 berkas $(95,06 \%)$, keperluan penelitian yaitu 54 berkas $(0,89 \%)$, pendidikan yaitu 58 berkas $(0,95)$, pengadilan yaitu 36 berkas $(0,59 \%)$ dan keperluan visum yaitu 28 berkas $(0,46 \%)$.

2. Pelaksanaan pelepasan informasi medis dari 3 orang pegawai sudah sesuai dengan regulasi pelepasan informasi dan 1 orang belum sesuai yaitu pada pelepasan informasi yang diminta keluarga/pasien seharusnya pasien membawa fotocopi KTP dan kartu keluarga, ternyata petugas tidak paham dalam menginformasikan berkas yang akan dilengkapi oleh keluarga.

3. Rumah sakit IPI belum memiliki SOP pelepasan informasi, yang ada hanya regulasi pelepasan informasi.

Berdasarkan kesimpulan diatas disarankan kepada rumah sakit untuk membuat SOP tentang prosedur pelepasan informasi, sehingga petugas mampu memberikan pelayanan yang optimal terkait pelepasan informasi kepada pihak-pihak yang membutuhkan pelepasan informasi rekam medis.

\section{REFERENCES}

[1] U. D. Negara et al., "UU tentang Rumah Sakit," vol. 4, no. 1, pp. 1-12, 1945.

[2] PERMENKES RI No 269/MENKES/PER/III/2008, "Permenkes RI 269/MENKES/PER/III/2008," Permenkes RI No 269/Menkes/Per/Iii/2008, vol. 2008. p. 7, 2008.

[3] B. Sampurna and G. R. Hatta, Pedoman Manajemen Informasi Kesehatan Di Sarana Pelayanan Kesehatan, Ed. rev. Jakarta: Penerbit Universitas Indonesia (UI-Press), 2008.

[4] E. Rustiyanto, "Statistik Rumah Sakit Untuk Pengambilan Keputusan," Yogyakarta: Graha Ilmu. 2010.

[5] N. 26. Permenkes, "Permenkes No. 269/Menkes/Per/III/2008:Rekam Medis.” p. 7, 2008.

[6] UU RI Nomor, "UU No. 29 Tahun 2004 Tentang Praktik Kedokteran," Aturan Prakt. Kedokt., pp. 157-180, 2004.

[7] Erlindai and T. Yulita, "Analisis Sistem Pelepasan Informasi Rekam Medis Dalam Menjamin Aspek Hukum Kerahasiaan Rekam Medis Di Rumah Sakit Imelda Pekerja Indonesia Medan Tahun 2018," J. Ilm. Perekam dan Inf. Kesehat. Imelda, vol. 3, no. 1, pp. 394-403, 2018.

[8] S. Siswati, Adinda and R. Agnesia, "Tinjauan Pelaksanaan Pelepasan Informasi Medis Kepada Pihak Ketiga Untuk Klaim Asuransi di Rumah Sakit Muhammadiyah Taman Puring Jakarta Tahun 2018," MEDICORDHIF J. Rekam Medis, vol. 5, no. 01, p. 8, 2018.

[9] K. Bpjs, D. I. Rsu, D. Ponorogo, and I. Sureni, "GLOBAL HEALTH SCIENCE ----http://jurnal.csdforum.com/index.php/ghs GLOBAL HEALTH SCIENCE , Volume 3 No . 3 , September 2018 ISSN 2503-5088 ( p ) 2622-1055 ( e ) Berkas Klaim, Rawat Jalan masuk RM Koding Mengurutkan pertanggal pelayanan Kirim berkas ke ," vol. 3, no. 3, pp. 175-180, 2018.

[10] Awal Isgiyanto, Teknik Pengambilan Sampel pada Penelitian Non-Eksperimental, 1st ed. Jogjakarta: Mitra Cendikia, 2009. 


\section{BIOGRAPHIES OF AUTHORS}

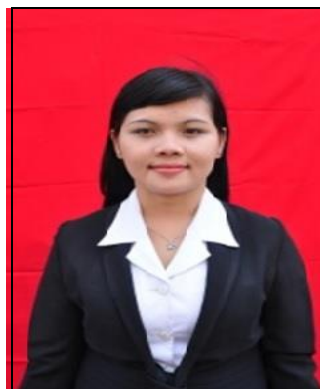

Erlindai, Gelar D-III diperoleh dari Akademi Kebidanan Imelda Medan, Jurusan D-3 Kebidanan pada tahun 2009, Gelar Sarjana diperoleh dari Sekolah Tinggi Ilmu Kesehatan Deli Husada Delitua tahun 2013, Magister Kesehatan diperoleh dari STIKes Deli Husada Desitua, jurusan Ilmu Kesehatan Masyarakat pada tahun 2015. Saat ini aktif sebagai dosen tetap di Prodi D-3 Perekam dan Informasi Kesehatan Universitas Imelda Medan dan menjabat sebagai sekretaris LPMI. 